\title{
A Study of the Impacts of Political Parties on Good Governance: A Case Study of Balochistan
}

\author{
Muhammad Zareef ${ }^{1} *$, Muhammad Hassan ${ }^{2}$, and Amir Jan ${ }^{3}$
}

\begin{abstract}
The paper aims to explore the role and impacts of the political parties on good governance in Balochistan. However, Balochistan has a history of fragile political parties- have functioned under the mercy of successive federal governments which cared and focused less attention towards the largest interest of the people of Balochistan since 1947. Thus, the research paper indicated that the political parties in Balochistan are more centre-oriented and intend to ensure their political power in province rather than serve the people of Balochistan in a general. This research paper intends to address the question that why the political parties of Balochistan have been failed to ensure strong political stability and good governance in Balochistan. This paper pointed out that the political parties have been in state of conflict for the personal and local interests which ultimately put bad impacts on the good governance of the province. Hence, this research paper illustrated that the lack of political awareness and Sardari system of Balochistan also put negative impacts on the governance of Balochistan. In this pattern, the research paper is based on the qualitative approach in nature - explored the different facts, and investigated the historical event in order to find out the cause of weak political system in Balochistan.
\end{abstract}

Keywords: Good governance; Sardari system; Political engineering; Political parties; Balochistan; Pakistan.

\section{Introduction}

Balochistan is the largest province of Pakistan, and occupies $44 \%$ of the total territory of the country (Faiz, 2015), as enriched in term of mineral and natural resources. Balochistan integrates six divisions and thirty-two districts, comprises a total population of 12.34 million (Nasir et al., 2019). The province also shares the borderline with Afghanistan on the North, Iran on the West, Sindh on the East and South with Arabian Sea which is the busiest ocean in term of trade activities. Balochistan is situated on the South-Eastern a part of the Iranian plateau that is extremely important in term of international trade and oil and transit route. Most importantly, Balochistan is bestowed with mineral and natural resources naturally.

\footnotetext{
${ }^{1}$ Department of Political Studies, Lasbela University of Agriculture, Water and Marine Sciences, Uthal, Lasbela, Balochistan, Pakistan.

${ }^{2}$ National Institute of Historical and Cultural Research (NIHCR) Quaid-i-Azam University Islamabad, Pakistan.

${ }^{3}$ Department of Political Studies, Lasbela University of Agriculture, Water and Marine Sciences, Uthal, Lasbela, Balochistan, Pakistan.
}

*)Corresponding Author.

Email: balochzareef088@gmail.com 
Despite its unique geo-strategic location and geo-political importance; Balochistan is one of the least developed and the most backward provinces of Pakistan. Unlike the other provinces of Pakistan, the CPEC province of Pakistan has deprived of political, social, and economic attention due to which it failed to ensure good governance in Balochistan at permanent basis. It does not only lack the socio-economic and infrastructural development, it has a failed history of fragile and easily-driven political parties whose roles in the development of province have been question mark. Balochistan's Political Parties which include National Party (NP), Balochistan National Party Awami (BNP-A), Balochistan National Party Mangal (BNP-M), Jahmori Watan Party (JWP), Pashtunkhwa Milli Awami Party (PMAP), National Awami Party (NAP), and recently formed Balochistan Awami Party (BAP), have been ruling the province since early 1970s. There is no doubt that the political parties can play a vital role in associating democratic principles in transitional societies and ensuring so many political and economic developments. However, the political parties are the only foundations for assigning the voices of ordinary people to the assemblies. There is no hesitation that parties are the important parts of the contemporary democratic system which address the issues of common people in the parliament.

The political parties perform the several functions - are necessary for the public development. The political parties having seats in parliament which stand more strengthened to raise voice for the political system in their particular area, and highlight the issues of their people. Thus, the Political Parties in Balochistan have been so weak and fragile which did not only fail to address the genuine issues of the people of Balochistan; they have also failed to strengthen themselves at national level. It has been the disappointing fact to learn that the Balochistan political parties have been witnessed either playing the ethnic or religious cards (Akhtar, 2013) to ensure the political growth and adjustment of seats in the assemblies only. Most importantly, their political activities have been limited until the end of their term from one election to another one. At the federal level, they do not exert any influence and pressurize the federal governments to pay heed to the issues of Balochistan since they have always faired of losing their seats. On the other hand, Balochistan main problem are federally-centred in nature which cannot be solved at provincial level with the limited political power at provincial level. The issues in the province will not be resolved if the federal government does not acknowledge the existence and role of political parties in Balochistan. It is extremely important to note that the strong political party system in Balochistan can only ensure good governance in Balochistan became political parties have a major role to play.

Another important reason impacted the good governance in Balochistanhas been the untimely interference of the political leadership in the administrative issues, creating disturbance for civil servants and staff, such as transfer of posting for the benefit of their workers and followers (Ahmad \& Akif, 2007). 
Political parties in Balochistan are essentially fragile and weak in nature due to which they have been failed to form the government in whole to have a majority role in Assembly where they could put a great impact on policy making process. Weak political system in Balochistan could also never put strong political pressure on the federal government to get their attention to play their part in Balochistan. Another reason for the failure of the political parties in Balochistan is that they lack well- educated and honest political leaders, and mostly they are from tribal or nationalistic background whose interests have also been limited to themselves only. Thus, good governance in Balochistan has rarely been witnessed.

\section{Causes of Failure of Political Parties in Balochistan, Impacts on Good Governance}

Good governance is an essential for the progress of any region or nation. Nations have become economically prosperous and politically powerful through only with assistance of good governance. Balochistan is known as the heart of Pakistan, and enriched with the precious natural and mineral resources. Importantly, the conclusion of China Pakistan Economic Corridor (CPEC) Project and construction of Gwadar deep seaport are the future hopes for the development and prosperity of the province (Saleem, 2017). In addition to catch and cash the future developments, strong political parties in Balochistan are the inevitable since they ensure peace, security and top of all good governance in Balochistan. But, unfortunately, the province presently is facing many challenges - do not allow the province to prosperous economically. The political instability of the province is one of main reason of bad governance in Balochistan. The bad governance can be termed as a major cause in setback in the fields of education, health, agriculture, social and economic development. The following enlisted causes are highlighted so that they are addressed timely for the sake of good governance in Balochistan.

\subsection{Interruption in Political Process}

Balochistan has faced political instability due to interruption of many factors in political and election process of Balochistan (Baloch, 2018). An interview with Qadir Nahil, the Central Information Secretary of Hazara Democratic Party, finds the fact that there exist too many hands in political process of Balochistan which have badly disturbed the political setup of Balochistan. He Further, elaborated the situation, saying that in Balochistan, there always exists two diametrically opposite political structures (Pro-nationalism versus Pro-center) both have ultimately disturbed the political environment in Balochistan. The Former Chief Minister of Balochistan- Dr. Malik Baloch opined the similar views that "The political process in Balochistan disrupted due to confrontational structure of opposite forces and added that grass level politics is lost its ground". Baloch nationalist parties view that pro-centre forces always make the province government for their personal vested interest to make sure their political survival (Jahangir, 2020). There is no denying the 
fact that until and unless common people oriented political parties are allowed in the politics of Balochistan to play their part, the issues of good governance would be at risk. Unlike the other provinces of Pakistan, Balochistan needs the strong political parties that could address the issues of Balochistan at national level. The province political setup is dominated by some nationalistic political figures and some Sardars who never represented the general masses of Balochistan. Thus, Sardari and weak nationalistic political system has paved the way for the different non-political elements to intervene in the political process of Balochistan.

\subsection{Conflict between Nationalist Parties and Pro-Centre Parties}

According to Central Information Secretary of Hazara Democratic Party, Qadir Nahil, Balochistan parliamentary politics is the process of the struggle and the sacrifices of the political personalities who always complain that their vote bank is manipulated. There is another fact that the federal parties have never succeeded in Balochistan, but they have been successful in ruling the province as Balochistan, itself does not have strong political parties. The people of Balochistan prefer nationalist politics, despite of federal support to the tribal leaders in the province. This is what true workers have never been produced in Balochistan. Moreover, the preference and interest of Balochistan's folks towards Balochistan politics have been limited due to political unawareness. From the above discussion, analysis can be drawn that there always existed a conflict between the nationalist political parties and pro-centre political parties for power gaining in Balochistan politics. The confrontation between pro-centred and nationalist parties in Balochistan has been affecting the governance of Balochistan. In this given scenario, procentre parties reined the Balochistan political system for many years without any political resistance. However, they always lacked public support. Mainstream political parties have less influence in interior Balochistan and remain the dependent on tribal hierarchy for their political ambitions (Mirza, 2013). As a result, the good governance of Balochistan has been at risk.

\subsection{Confrontation of Nationalist Parties with Feudalist Parties}

The conflict between nationalistic and feudalist political parties in Balochistan is not deniable since 1970s. The tribal leaders and feudalists have been brought into power in order to pacify the tribal areas which has been actually a failed strategy. Because of the tribal leaders lacked public support and as a result, they never ever worked for the development of the province at general and people at particular. Sardars rather remained the key cause of backwardness of the province. Sardari system is the responsible for poverty, illiteracy, the petty share in national economy, inaccessibility to clean water, unavailability of food and health, and dearth of educational and other public amenities in Balochistan (Bibi, 2015). A personal interview with Dr. Abdul Malik Baloch, former Chief Minister of Balochistan highlighted the fact that the strong support of the federal government towards Sardari system impacted 
the good governance of Balochistan. He further, stated that the prime motives of nationalist parties are anti-secularism, anti-feudalism, anti-capitalism, antitribalism, and anti-lords while the pro-central parties function according to their own interests which are consisted of feudalism and landlords. Therefore, the tribal based parties and government in Balochistan had no interest to work for the good governance of Balochistan. They have always worked within the framework of their personal interest parameter and entertained their personal interest rather than working honestly for the province at large.

\subsection{Bureaucratic Incursion}

In order to investigate the conspicuous failure of political parties in respect to good governance in the province, the bureaucratic incursion in political domain is a serious factor. According to Qadir Nahil Central Information Secretary of Hazara Democratic Party (interview, 2020), bureaucracy has its own systematic function, behaviour and structural body which is apart from politics. However, here in Balochistan, bureaucratic involvement is observed so often which is not a good sign for the good governance of Balochistan. $\mathrm{He}$ further argued that the issue of good governance in Balochistan can never be addressed unless the bureaucracy and provincial representatives would come together in a collective-oriented page to define their area of powers. Specifically, it would take much time to change the old system which is prevailingly traditional and bureaucratic dominated. The political leaders were fragile during the period of Ayub Khan in which the matters of institutes were handled by bureaucracy and till now they want their hegemony. However, with the passage of time, the process of involvement in bureaucracy has been changed. But, it still exists in Balochistan in the different shape. The political parties and bureaucracy are two different institutions which are to work under their domain.

\subsection{Rampant Corruption among Political Parties}

Corruption is another major cause of political instability and bad governance in Balochistan. The lack of good governance in regard with role of political parties is the rampant corruption which is taking place in political parties of Balochistan that is creating obstacle in setting up effective model of governance. Workers and leadership within parties are motivated by money and they might think that their ultimate role in political parties to make their balances greater after coming to power. In an absolute mean, the tribal system is the root cause of corruption since the political parties which belong to tribal culture, tend to less care about public demands and intend to make money via politics (Sehgal, 2012). Their status in society seems to be well- established that they don't fear of losing the support. Therefore, they tend to involve in corruption.

An interview with a political member of Balochistan Nation Party, Akbar Mengal, identified the fact that corruption among political parties is the main 
cause of bad governance in Balochistan. They also lack any check and balance to stop their corruption in Balochistan.

\subsection{No Free and Fair and Transparent Election Process}

The lack of transparent and free election in Balochistan is termed to be a hindrance towards the good governance in Balochistan because publicoriented and true representatives of people get discouraged in election. Unlike other provinces of Pakistan, Balochistan does not have its own strong political parties at national level which could encounter the election-ragging process. So, it is the federal government which helps the provincial government to be formed. According to Balochistan National Party (M), the governments in Balochistan are formed by the successive federal governments which do not have any interest for the people of Balochistan in a general. They further, say that Baloch political ruling elites who are more concerned about being in power and making money, in collusion with the federal government rather than working for the good governance in Balochistan (Sial, 2007). Moreover, the parties which are made within two days and come into power would not care for the interests of the people of Balochistan. Adding more to that, these business-minded and non-political people are the real cause of bad governance in Balochistan since they do not have any interest for the people in grassroots. Until and unless, middle class political figures are allowed to fight election freely, the good governance would be at risk in Balochistan.

\subsection{Inconsistency in Policy}

The role of political parties in respect to good governance lies in how policies are designed to achieve their end. It ought to be noted that inconsistent policies cause a great trouble in system of good governance in Balochistan. As far the political system in Balochistan is concerned; it has run under the mercy of federation since 1970s. Even the tenure of a middle-class Chief Ministership, Dr. Abdul Malik was not allowed to be completed who was committed to bring political transparency and stability in Balochistan. The projects which were started during Dr. Abdul Malik tenure were rarely seen to be carried out further. Thus, the inconsistency of policies would put bad impacts on the good governance of the province. People in Balochistan often complain about deprivation and alienation in Balochistan which can only end and settle down if the public-oriented policies are given more preference. They continuity of policies of previous governments are often stopped that is wastage of money as well.

\subsection{Lack of Accountability}

In every democratic system, transparency and accountability of government are the inevitable factors for good governance. Transparency in process and accountability in results decides where a system is heading to. There is no transparency, merit and commitment due to lack of accountability whose impacts are directly felt on the good governance in Balochistan (Mirza, 2013). 
An interview with Dr. Abdul Malik Balochistan investigated the fact that election transparency would ensure the election of right and deserving candidate who never let his people down, rather he would be an accountable for the work, projects and any good and bad governance in Balochistan. Government is the main machinery of the province which works for the betterment, prosperity and development of the people. However, on its failure to function, it is not only accountable to its people; it is also answerable to its people over each issue related to public. Thus, good governance would be ensured throughout the province if accountability is taken by the political leaders.

\section{Critical Analysis on the Performance of Political Parties in Balochistan}

It is the disappointing fact to learn that the roles of political parties of Balochistan -have been so weak and fragile since Balochistan got the status of Province in 1970, because Balochistan failed to establish a strong national level political party. As a result, the political parties of Balochistan have been functioning under the mercy of federation. No doubt, the early phase of political system of Balochistan had the strong political leadership in shape of Nawab Khair Bakhsh Marri, Nawab Akbar Khan Bugti, Sardar Attaullah Khan Mengal, however; they were soon disappointed to continue their political struggle in Balochistan because they were not happy with the Central government of Pakistan. The early phase of Balochistan's political system which started in 1970s brought the entire political leader of Balochistan under the banner of National Awami Party (NAP) and thus, the political activities gained momentum around. The following the election of 1977, the National Awami Party won 8 seats out of 20 seats in Balochistan Assembly (Zeb, 2018), however, it failed to perform well due to its inability within its political structure. Most importantly, the pressure of federal government on NAP made it the difficult for NAP to continue its government in Balochistan. (Kiran, 2016). During this period, the Chief Ministership was awarded to Sardar Atta Ullah Mengal, however, this did not last long, and soon he was replaced by the representatives of PPP. Actually, these were the initial political engineering in Balochistan which put the negative impacts on good governance in Balochistan. This political engineering rather gave birth to rebellions in Balochistan which could have been settled via political means at initial stages. However, this entire situation ended in political tension and rebellion clashes in 1977, and no significant development was witnessed onward (Bansal, 2006).

On the fall of Bhutto and rise of Zia-ul-Haq in politics of Pakistan, from 977 to 1985, a good gesture was seen in Balochistan which gave the birth to a peace political environment in Balochistan. Political activists who were detained during Bhutto's tenure were released. The main political personalities brought in an appearance under general amnesty. In this period, no doubt, Balochistan was directly controlled by centre, but they were very rarely political tension in Balochistan. 
After Zia regime, another period of political instability was witnessed in Balochistan from 1986 to 1996. Almost each year, government of Balochistan was replaced by another government. Despite the fact that this era was associated with the rule of independent political parties, however, no political party in Balochistan could execute its independent political decisions. Therefore, this era could not see any significance development in Balochistan. It is noteworthy here that a few central controlled programs- were initiated to assuage the pain of people of Balochistan, however; ended with no result.

The period from 1997 to 2007, witnessed a bunch of developmental work in Balochistan, but all were carried out under central government of General Pervaiz Musharraf. This period was the combination of the most stable and the most unstable period in Balochistan. Especially, the following of the Martial Law of Musharraf in 1999, many development projects were initiated in Balochistan. For the first time, Balochistan saw an infrastructural development in every mega city. Many programs were launched in term of road, schools and other developmental activities that created a raise of hope among the people of Balochistan. However, after the killing of Nawab Akbar Khan Bugti in August, 2006, the laws and order situation in Balochistan became extremely tense which gave the birth to another insurgency in Balochistan which still continue in the different parts of Balochistan. It is to be noted that this insurgency did not only create political instability and disturb Central-provincial nexus; it also created a tough political environment for the Baloch political parties to carry out their political struggle in Balochistan.

After the departure of General Pervaiz Musharraf in 2007, a Balochistan based government was installed in Balochistan with the support of PPP which was in the majority in the federation. The aim of bringing Raisani into government in Balochistan was to bring peace and restore political activities in Balochistan. This Raisani government was the most stable regime in term of political development in Balochistan. No doubt, it was under the leadership of a tribal leader; however, he was well-learnt about the issues of public in general. PPP government in centre with help of Balochistan government focused on providing employment opportunities and developmental packages to recover the damage, done by previous governments of Balochistan. In this period, multiple vacant posts were filled and NFC award, a multi-billion rupees' package, were launched for Balochistan. So for, this government performed better as compared to others due to many reasons.

After the election of 2013, Dr. Abdul Malik Baloch, a middle class was made the Chief Minister of Balochistan for the first time with support of federal government of Mr. Nawaz Sharif. As far as the performance of Middle Class government was concerned, the government between 2013 and 2015, focused on education and law and order sectors which developed into many folds. However, on other fronts, government failed to perform such as assuaging the pain of people in term of employment, roads, hospital and other civic facilities. The pains of Baloch people were further, added as Dr. Abdul Malik was removed after two and half years and Sardar Nawab Sana Ullah 
was brought into power. This time the political engineering of federation in Balochistan further, created political anxiety among Baloch political leadership of Balochistan. The end of Dr. Malik regime brought the sense of grievances among the people of Balochistan as once again a Sardar was allowed to rule in Balochistan. Sana Ullah Zehri, having no mercy for the common people of Balochistan, ruined the good work which was done during Dr. Abdul Malik Baloch regime in Balochistan. However, his tenure was short-lived due to his political rigidness.

The 2018 election brought surprise for the entire political parties of Balochistan which have been struggling hard to gain political power in Balochistan. Into their surprise, a newly born political party namely, Balochistan Awami Party (BAP), having no political history, took away majority seats in the Provincial Assembly and finally formed the government. The government of BAP no doubt became successful to run the political affairs of Balochistan, but it has been failed to bring any political impact on good governance in Balochistan. Such political engineering always put severe impacts on the good governance. The government of BAP which was run by Jamal Kamal Khan faced many political hindrances within its political parties. A group of BAP politicians overthrew the government of Jam Kamal Khan, saying that Jam government had failed to bring good governance in the province. Thus, he was once again replaced by Abdul Quddus Bizenjo in October, 2021. The political engineering in Balochistan by the federation has not only disturbed central-province relationship, it also created political mistrust among the political leadership of Balochistan which is the main cause of political tension of Balochistan.

\section{Recommendations}

The ultimate objective of research was to point out the chronic flaws in governance in context to role of political parties and find the most comprehensive solutions to problems of governance in Balochistan. Political parties in Balochistan are required to strengthen their link with public for support in election instead of setting in the cradle of federal government. Furthermore, the political parties must ensure that mandate of people to whom they confer would be respected honestly. Addition to it, political parties need to solidify their roots in public, because this is only way they can free themselves from federation support. Moreover, combined efforts should be made to bring transparency in election process which is the pride and pillar of democratic setting. This would result in exclusion of irrelevant parties in government. Besides this, political parties must ensure the consolidation of civil institutions for carrying out the government policies. In short, strengthening the root and link to public, insertion of transparent election, consolidation of civil institution and respect the public mandate which is essential for good governance in Balochistan. These measures would automatically result in exclusion of unnecessary involvement of the successive central governments and bureaucratic incursion. In this way, the stature of 
governance can be immensely improved under a democratic structure. In order to establish good governance in Balochistan, people should be empowered and the representatives of people should not be imposed by force but the people should be given the power to elect their representatives through voting. Free and fair elections should be mandatory. With the insurance of supremacy of the parliament, the press should be given freedom of expression by ensuring the 18th amendment and province must have the choice to take decisions independently, the decision concerning the resources have to be handed over to province. For good governance in Balochistan, it is the significant for both federal and provincial level political parties to maintain strong ties with each other, because it has always been seen that federal political parties have ignored the interest of Balochistan. However, it has noted that the federal leadership of the political parties has not shown interest in the politics of Balochistan, even when their party was ruling in the province.

Balochistan is inhabited by two big ethnic groups, namely, Pashtun and Baloch. Therefore, Pashtun and Baloch nationalist political parties should work with collective efforts to strengthen the institutions in Balochistan, instead of pursuing politics on basis of language for the sake of good governance. In the context of Balochistan's politics, most governments are formed under coalitions and sometimes the ruling political party compromises with its allies on certain issues to please them which lead the governance issues. Thus, corruption increases, and it is an important that the assessment process may be made an equal for everyone. For bringing good governance in Balochistan, it is the necessary that the political parties of Balochistan to focus on education, health and basic infrastructures of the province instead of transfer and posting of their workers and followers. Because the government of the parties that come Balochistan to start the process of transfer and posting to reward their people and instead of focusing on governance. To ensure good governance in Balochistan, the area of powers between politicians and bureaucrat are to be defined well.

\section{Conclusion}

The study conducted to find out the role of political parties in respect to the level of good governance in Balochistan, which is a major work since it would be extremely beneficial for the policy makers of Balochistan. The study has been taken in the historical perceptive to analyse and investigate the contemporary challenges of good governance in Balochistan. It is to be noted that the concerning conditions of governance of Balochistan compelled the researcher to examine and find out the gap between political parties and good governance in Balochistan. The historical precarious situation of the bad governance of Balochistan can be traced from the non-existence of legal and honest bureaucratic and political structure that allowed tribal chiefs and other non-political elements to disturb the governance of Balochistan.

The political parties of Balochistan have been function under the command of successive federal governments that never allowed true 
leadership of Balochistan to rule in Balochistan. The role of political parties in Balochistan seems to be symbolic as power lies in the hand of federal governments. The political inference of successive federal governments in Balochistan political system resulted in an incessant interruption in political process and affected the good governance of Balochistan. The political parties remained bereft of public supports and sat in cradle of federal government to strengthen to political careers. This nexus walked over the appropriate political demagogues and brought in an inconsistency in policy and dependent decision making process in Balochistan. In this entire scenario, the political parties of Balochistan failed to fight for the good governance of Balochistan in latter and spirit.

\section{References}

Ahmad, R., \& Akif, S. A. (2007). Technocratic Solutions versus Political Realities: Implementing Governance Reforms in the Balochistan Province of Pakistan. Policy and Society, 26(2), 83-108. https://doi.org/10.1016/S1449-4035(07)70109-1

Akhtar, N. (2013). Ethnic Politics in Pakistan By Nasreen Akhtar. Pakistaniaat: A Journal of Pakistan Studies, 5(3), 1-23.

Baloch, M. A. (2018). The Origin of Jirga in Balochistan. Hanken, 10, 34-40.

Bansal, A. (2006). Balochistan: Continuing Violence and Its Implications. Strategic Analysis, 30(1), 46-63. http://idsa.in/system/files/strategicanalysis_abansal_0306.pdf

Bibi, H. (2015). Genesis Of Baloch Alienation: Diagnosis and Prognosis. Pakistan Vision, 21(2), 173.

Faiz, J. (2015). Politics of Education, Conflict and Conflict Resolution in Balochistan (Issue February). Westminster.

Jahangir, J. (2020). Political Culture of Balochistan during Military Regime of General Pervez Musahrraf and Indian Interest in Balochistan. Journal of Indian Studies, 6(1), 101-136.

Kiran, N. (2016). Balochistan and the Federal Cabinet of Pakistan, 1947-1977. Pakistan Historical Society. Journal of the Pakistan Historical Society, 64(1), 19.

Mirza, Z. L. (2013). Balochistan-Past, Present and Future. NDU Journal, 27, 21-34. http://www.ndu.edu.pk

Nasir, H., Ahmed, A. Bin, Tariq, M., \& Kazmi, S. A. A. (2019). Evaluation and Analysis of Sustainable Microgrids and Communication Policy: A test case of Balochistan. 2019 4th International Conference on Emerging Trends in Engineering, Sciences and Technology (ICEEST), October 2020, 1-7. https://doi.org/10.1109/ICEEST48626.2019.8981694 
Saleem, A. H. (2017). CPEC and Balochistan: Prospects of Socio-political Stability. Strategic Studies, 37(4), 118-132. https://www.jstor.org/stable/48537575

Sehgal, I. (2012). BALOCHISTAN QUAGMIRE. Defence Journal, 16(3), 14.

http://search.proquest.com/openview/e7700f188b9dc15ccb403bb63cb5 ac8c/1?pq-origsite $=$ gscholar\&cbl $=616545$

Sial, S. (2007). CPEC in Balochistan: Local concerns and implications Introduction: Significance of Balochistan for CPEC and BRI. Pak Institute for Peace Studies, March.

Zeb, R. (2018). Pakistan's Political Chess Board: Bhutto, Bugti and The National Awami Party Government In Balochistan (1972-1977). Source: Journal of South Asian and Middle Eastern Studies, 42(1), 6787. https://doi.org/10.33428/jsoutasiamiddeas.42.1.0067 